\title{
A Study on the Possibility of Applying National Competency Standards for Software Education
}

\author{
Jeongwon Lee ${ }^{1}$ and Choong Ho Lee ${ }^{2}$ \\ ${ }^{1}$ Student, Department of Information Communication and Engineering, Hanbat National University, Daejoen, \\ 34158, Republic of Korea \\ ${ }^{2}$ Professor, Department of Information Communication and Engineering, Hanbat National University, Daejoen, \\ 34158, Republic of Korea
}

\begin{abstract}
Background/Objectives: In this study suggests that the NCS-based curriculum is applied to secondary and tertiary education such as universities, colleges, vocational schools, and specialized high schools. Methods/Statistical analysis: In this study, a qualitative research and analysis method was used for the application method and application cases for software education based on the NCS information and communication field system under development. Findings: Presenting the necessity of reforming information education centering on software education, the source of national competitiveness for fostering creative talents who will lead students' dreams and meals and lead the era of happiness education and creative economy through 'Primary and Secondary Software Education Promotion Plan' Was intended. Improvements/Applications: In order to prepare educational indicators of knowledge, skills, and attitudes leading to competency, a mid-to-longterm standard development plan has been established between the Ministry of Education and the Ministry of Employment and Labor from 2010 to 2014.
\end{abstract}

\section{Index Terms}

Computer Education, Software Education, Curriculum, Teaching Methods, NCS

\author{
Corresponding author : Choong Ho Lee \\ chlee@ hanbat.ac.kr \\ - Manuscript received April 8, 2019. \\ - Revised May 20, 2019; Accepted June 20, 2019. \\ - Date of publication June 30, 2019 \\ (C) The Academic Society of Convergence Science Inc. \\ 2546-1583 $\odot 2017$ IJEMR. Personal use is permitted, but republication/redistribution requires IJEMR permission.
}




\section{INTRODUCTION}

Since 2002, the Ministry of Education, Science and Technology has been operating the National Competency Standards (NCS) program, which not only develops national training capabilities but also develops education and training courses based on job performance capabilities required by industrial sites. Through content linkage between standards and qualification questionnaire standards, efforts have been made to foster and utilize human resources that reflect the needs of industrial sites [1-2].

In 2013, the National Ability Standard for Information and Communication was completed, and NCS-based curricula were developed and introduced by front-line colleges, Meister High Schools, companies, and vocational training institutes. Some opinions were improved by vocational training institutes, and the NCS classification system for all sectors began to be revised in 2014.In the case of the information and communication sector, the introduction of the classification system was partially reorganized in 2014. In 2015, the entire introduction has been left.

NCS, which has been the core project of the government's national task 'Creating Conditions for Competency-Based Society' based on the era of national happiness, will be developed and distributed to junior colleges, Meister High Schools, companies, and vocational training institutes. Since 2016, it has been aimed at full utilization [3-5].

The National Curriculum Revision Research Committee has continuously conducted research to revise the curriculum in response to the necessity of the Integrated Curriculum Integrated with Curriculum and Science, and the 2015 National Curriculum Reform Study was conducted by the Korea Institute for Curriculum and Evaluation. It is based on the Basic Research on Improving General Curriculum of National Curriculum and the current status of many 2009 revised curricula. The revision of the national curriculum reflects various needs, including the times and social needs, by improving them on the basis of the curriculum currently being implemented. Second, the study aimed to develop a national curriculum that induces the development of textbooks that enable teachers to demonstrate their expertise as a tool for teaching. Finally, the vision of revision is to immerse students in a small number of important knowledge, explore them deeply, and creatively solve related problems in new contexts [68].

The purpose of this study is to explore the application of SW curriculum based on the new system of NCS information and communication and to suggest the possibility of application.

\section{THEORETICAL BACKGROUND}

\section{A. Recent environmental changes}

Since the advent of smartphones in 2010, software is rapidly transforming into a' software-driven society' that determines the competitiveness of individuals, businesses and governments. Software that was previously treated as an accessory of hardware (HW) is now an intangible product - It creates important added value that determines service value, and without SW, maintaining and improving the nationwide competitiveness is changing to an industrial structure that is no longer possible.

Korea lacks the preparation for 'SW-oriented society' compared to its competitors in the nation and society and lacks efforts to solve the decline in competitiveness through software. In spite of high education fever, SW education is showing a decline. In this regard, the government introduced the concept of a 'software-oriented society' in order to improve the quality of life and to enhance the competitiveness of companies and governments. It has suggested 'software-oriented society realization strategy'[9-10].

\section{B. Problems of Software Education in School Education}

In school education in Korea, there is a lack of systematic software education suitable for the development stage of students, and a systematic software (SW) education model for each school level is required.

In elementary school, there is a real need for systematic education because ICT and some SW basic education are mixed in technical, home and information subjects.

In addition, ICT-based information education, such as the use of computer devices and programs, does not meet the interests and interests of the digital information generation, and the support system for early detection and development of gifted students for software futures is the biggest problem. [11-12]

\section{Background of the National Competency Standards (NCS)}

Inconsistency between the industrial site and the training course and qualification test caused dissatisfaction with the education demand consumer (company and student), and the poor currency of qualifications was low. It was urgent to find ways to 
manage qualifications. In particular, the industry, which is a consumer, participated in the human resource development system in earnest and introduced NCS to improve the efficiency of human resource development (HRD) in the country [13-14].

\section{NCS ICT Classification System}

The National Vocational Competency Standard serves as a core foundation for human resource development, that is, the link connecting work, education, training and qualifications by systematically analyzing and presenting job demands at industrial sites.

The Table 1 shows the state of the national communication competency standard (NCS) information and communication sector.

Table 1. NCS ICT ClassifiCATION System

\begin{tabular}{cl}
\hline $\begin{array}{c}\text { Classification } \\
\text { system }\end{array}$ & \multicolumn{1}{c}{ Classification details } \\
\hline Main Category & Communication \\
Category & Information technology \\
Subclass & Information technology development \\
& SW Architecture \\
& Applied SW Engineering \\
& System Engineering \\
Segmentation & DB Engineering \\
& NW Engineering \\
& Security Engineering \\
& UI / UX Engineering \\
\hline
\end{tabular}

\section{E. Activation of Software Training}

There is a need for systematic education through public education so that all students can be provided with SW learning opportunities appropriate for their abilities and aptitudes.

After the 7th curriculum, ICT education has been provided.

There is a need for systematic education through public education so that all students can be provided with SW learning opportunities appropriate for their abilities and aptitudes.

It is necessary to revitalize elementary and secondary SW education in consideration of industrial demand and linkage with higher education [15-16].

The model of software education in elementary, middle and high school is shown in Table 2, Table 3 and Table 4.
Table 2. ELEMENTARY SCHOOL SOFTWARE EDUCATION MODEL PRESENTATION

\begin{tabular}{|c|c|}
\hline Classification & Model \\
\hline & SW literacy education \\
\hline $\begin{array}{l}\text { Educational } \\
\text { objectives }\end{array}$ & $\begin{array}{l}\text { Understanding SW Coding by Using } \\
\text { SW Tool }\end{array}$ \\
\hline $\begin{array}{l}\text { Course } \\
\text { Content }\end{array}$ & $\begin{array}{l}\text { Play-oriented activity learning } \\
\text { (Understanding Computing Thinking) } \\
\text { Learning using SW Tool } \\
\text { (Learn how to troubleshoot) }\end{array}$ \\
\hline $\begin{array}{c}\text { Creative } \\
\text { experience }\end{array}$ & $\begin{array}{l}\text { Logical Thinking Experience (SW } \\
\text { Coding Activity) }\end{array}$ \\
\hline
\end{tabular}

Table 3. PRESENTING MIDDLE SCHOOL SOFTWARE EDUCATION MODEL

\begin{tabular}{cl}
\hline \hline Classification & \multicolumn{1}{c}{ Model } \\
\hline $\begin{array}{c}\text { Educational } \\
\text { objectives }\end{array}$ & $\begin{array}{l}\text { SW literacy education } \\
\text { Improve algorithm understanding } \\
\text { problem solving }\end{array}$ \\
& $\begin{array}{l}\text { Troubleshooting project learning } \\
\text { (Program production basics) }\end{array}$ \\
Course & $\begin{array}{l}\text { Logical Problem Solving Skills } \\
\text { (Learn algorithmic procedure) }\end{array}$ \\
& $\begin{array}{l}\text { Computer program production } \\
\text { (Implementation of how the machine } \\
\text { Creative }\end{array}$ \\
\hline
\end{tabular}

Table 4. High School Software Education Model PRESENTATION

\begin{tabular}{cl}
\hline \hline Classification & \multicolumn{1}{c}{ Model } \\
\hline Educational & $\begin{array}{l}\text { Creative output production through } \\
\text { computer convergence activities and } \\
\text { college career linkage learning }\end{array}$ \\
& $\begin{array}{c}\text { Create creative idea deliverables } \\
\text { (Intensive Program Production) } \\
\text { Content }\end{array}$ \\
& $\begin{array}{l}\text { Programming language learning } \\
\text { (Intensive Problem Solving) }\end{array}$ \\
Creative & Computer System Convergence \\
experience & Activity (R \& Activity)
\end{tabular}




\section{F. Direction of Software Curriculum Reform by School Level}

In order to reorganize the software curriculum, there are active reviews on how to complete SW education in elementary and middle schools.

In addition, in order to actively develop SW educational programs and textbooks for creative hands-on activities from September 2014, the Ministry of Education and the Future will jointly call SW educational contents for elementary, middle and high schools in consideration of students' interests and aptitudes. Education, programming, etc.).

Table 5 shows the direction of software curriculum reform by school level.

Table 5. SW CURRICULum ReORGANIZATION DiRECTION BY SCHOOL LEVEL

\begin{tabular}{|c|c|}
\hline Division & Reorganization Direction \\
\hline $\begin{array}{c}\text { Elementary } \\
\text { School }\end{array}$ & $\begin{array}{l}\text { Reorganization of information-related } \\
\text { curriculum contents into SW-based } \\
\text { literacy contents }\end{array}$ \\
\hline middle School & $\begin{array}{l}\text { Reorganization of information related } \\
\text { curriculum contents and conversion } \\
\text { of information curriculum into SW } \\
\text { curriculum }\end{array}$ \\
\hline high school & $\begin{array}{l}\text { Transition of Information Curriculum } \\
\text { from Advanced Selection to SW } \\
\text { Curriculum General Selection }\end{array}$ \\
\hline $\begin{array}{c}\text { Vocational } \\
\text { school }\end{array}$ & $\begin{array}{l}\text { In 2013, we expanded the SW } \\
\text { departments for more than } 20 \\
\text { specialized high school and Meister } \\
\text { high schools and developed and } \\
\text { distributed related contents as NCS- } \\
\text { based learning modules }\end{array}$ \\
\hline
\end{tabular}

\section{G. Establish a Support System to Activate Software Education}

Since the second half of 2014, the software operation guideline has been developed and distributed, and since March 2015, the Ministry of the Future and the Ministry of Education have jointly promoted software research, pilot school designation and operation by school level. To this end, we have been conducting training for dedicated software teachers since September 2014.

Table 6 shows the support system for software activation by school level.
Table 6. SW ACTIVATION SUPPORT SYSTEM BY SCHOOL LEVEL

\begin{tabular}{|c|c|}
\hline Division & Reorganization Direction \\
\hline $\begin{array}{c}\text { Elementary } \\
\text { School }\end{array}$ & $\begin{array}{l}\text { Actively support SW education } \\
\text { Review budget and program support } \\
\text { plan to activate SW education in } \\
\text { regular curriculum or creative } \\
\text { experience activities }\end{array}$ \\
\hline middle School & $\begin{array}{l}\text { Review budget and program support } \\
\text { plan to activate SW education in } \\
\text { regular curriculum or creative } \\
\text { experience activities }\end{array}$ \\
\hline
\end{tabular}

\section{STUDY ON THE POSSIBILITY OF USING NCS-BASED SOFTWARE CURRICULUM}

\section{A. NCS-based software curriculum utilization module}

Establishment of a systematic software education system for each school level and a method of supplementing the software education that appeared at the stage of student development through the education and training system organized in the National Competency Standards. This paper suggests the possibility of using NCS-based software education.

The NCS-based ICT education system and the concepts by level are shown in Table 7 and Table 8 .

Table 7. NCS-BASED INFORMATION AND COMMUNICATION EDUCATION SYSTEM

\begin{tabular}{cl}
\hline \hline Level & $\begin{array}{c}\text { Applied SW Engineering Occupational } \\
\text { Education System }\end{array}$ \\
\hline 6 levels & $\begin{array}{l}\text { Application design } \\
\text { Integrated implementation } \\
\text { Software Engineering }\end{array}$ \\
& $\begin{array}{l}\text { Check requirements } \\
\text { Data input/output implementation }\end{array}$ \\
& Application implementation \\
& Developer testing \\
& Information system implementation \\
& \\
2 levels & Product Software Packaging \\
&
\end{tabular}


Table 8. NCS CONCEPT By NCS LEVEL

\begin{tabular}{ll}
\hline Level & \multicolumn{1}{c}{ Concept } \\
\hline Able to create new theories using the \\
best theories and knowledge in the \\
field, perform a wide range of \\
technical tasks with the best skills, \\
and grant the authority and \\
responsibility for the organization \\
and the work as a whole. \\
By using specialized theories and \\
knowledge in the field, they can \\
perform a wide range of tasks with \\
high skill and require obligations and \\
responsibilities for the results of \\
others.
\end{tabular}

The ability to freely use the theory and knowledge of the field within an independent authority, perform 6 levels various tasks with general skills, and transfer knowledge and know-how in the field to others.

The ability to perform very complex and unusual tasks using the theories and knowledge of the field within 5 levels comprehensive authority, and to convey the knowledge of the field to others.

The level of performing complex and diverse tasks with limited use of 4 levels theory and knowledge of the field within general authority.

The level of performing somewhat complex tasks using basic theories 3 levels and general knowledge in the field within the limited authority.

The level of performing procedural and routine tasks using general 2 levels knowledge in the field under general direction and supervision

The level of performing simple and repetitive tasks using basic general

knowledge such as literary
understanding and calculation ability
under specific instructions and
thorough supervision.

\section{B. Using NCS in Software Curriculum}

The NCS Learning Module serves as a guideline that clearly sets the goals and direction of learning so that the job skills required by the industry can be used in the education and training field.

The NCS Learning Module can be used as a standard textbook in specialized high schools, Meister High schools, colleges, educational institutions and training institutes of four-year universities, and workplace education institutes.

The linkage activities of NCS learning modules that can be used in industrial and educational sites are shown in Fig. 1.

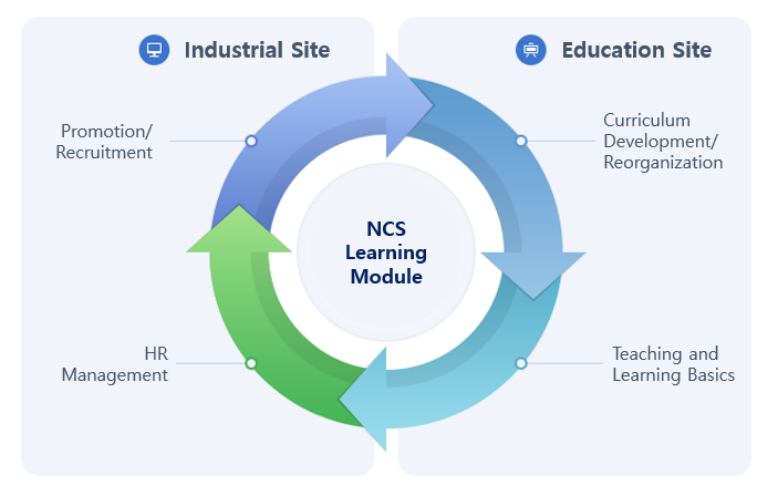

Fig. 1. NCS Learning Module Integration Activity.

\section{CONCLUSION AND SUGGESTION}

This study suggests that the NCS-based curriculum is applied to secondary and tertiary education such as universities, colleges, vocational schools, and specialized high schools.

Although the final development of the National Competency Standards (NCS) for the information and communication field has not been completed at the time of this study, the application method and application cases for the software education based on the NCS information and communication field system under development are being used. I suggested the possibility.

I hope that this study will be a starting point to derive the applicability of software (SW) education and to approach it more effectively when the final development of NCS system in information and communication field is completed. 


\section{REFERENCES}

[1] I. J. Joo, J. Y. Cho and G. B. Lim. (2010). The current issues and policy plans of the National Competency Standard(NCS) project, Korea Research Institute for Vocational Education and Training. Retrieved from https://www.krivet.re.kr/ku/da/kuBDBVw.jsp?_notiN $\mathrm{o}=\mathrm{G} 520100008 \& \_$prdcNotiDet $\mathrm{No}=2$

[2] Ministry of Employment and Labor. 2014. National Competency Standard-based Training Standards Training Course Organization Manual. Retrieved from https://www.ncs.go.kr/vt/guide/ncsTrainGuide.pdf

[3] Ministry of Education. 2014. The main issue of the 2015 integrated curriculum for literature and science. Retrieved from https://www.moe.go.kr/boardCnts/view.do?boardID= $339 \& l e v=0 \&$ status $Y N=W \& s=$ moe $\& m=02 \&$ opType $=$ N\&boardSeq $=56875$

[4] Ministry of Education. 2014. A plan to revitalize SW education in elementary and secondary schools. Retrieved from https://happyedu.moe.go.kr/happy/bbs/selectHappyAr ticleImg.do?bbsId=BBSMSTR_000000000192\&nttId $=3164$

[5] Ministry of Employment and Labor. 2014. 2014 National Competency Standard and Utilization Package.

[6] Human Resources Development Service of Korea(ncs.go.kr). 2014. Basic Vocational Ability Program: Learners-Information Ability.

[7] S. M. Kim \& K. S. You. (2015). The Effect of RobotBased STEAM Class on the Korean Learning of Multiculturul School Children -Focusing on After School Learning of Elementary School-, Journal of digital convergence, 13(8), 1-8.

[8] S. Y. Lee. (2010). Research of Effective Computer Teaching Program After Class In Elementary School : Focusing On Pupils In Jinhea, The Graduate School of Changwon University, Master's Thesis.

[9] S. H. Kwon. (1993). Education Technology, Yangseowon.

[10] S. W. Bae \& W. R. Cho. (1999). A study on the constructivist multimedia-assisted instruction in secondary school geography, Journal of the Korean Association of Regional Geographers, 5(1), 163-185.

[11] S. C. Kang. (2006). A study on the connection between the computer science education curriculum of university and that of primary and secondary school, The Journal of Korean Association of Computer Education, 9(3), 29-45.

[12] K. C. Hong. (2016). Novel Engineering and Computational Thinking, The Korean Association of Information Education Research Journal, 10(2), 1116.

[13] B. Y. Kang \& K. C. Hong. (2018). Novel Engineering Symposium and Integration for the 2nd Grade Focused on 'Where are the 100 heads of cabbage?'-, The Korean Association of Information Education Research Journal, 9(2), 271-276.

[14] W. J. Lee \& K. C. Hong. (2018). Maker Education Class through Novel engineering, -, The Korean Association of Information Education Research Journal, 9(1), 237-242.
[15] Yi, S. (2001). The Challenges and Improvement Direction of Technical Education in Response to Knowledge-Based Society. The Korean Journal of Technology Education, 1(1), 15-29.

[16] Department for Education in England. (2014). The national curriculum in England Framework document. 